\title{
Low Thoracic Epidural Anaesthesia for Elective Cholecystectomy in a Patient with Con- genital Heart Disease and Pulmonary Hypertension
}

\begin{abstract}
A 52-year-old male with pulmonary hypertension secondary to partial anomalous pulmonary venous return unassociated with atrial septal defect was given thoracic epidural anaesthesia for elective cholecystectomy. Partial anomalous pulmonary venous return is a rare congenital anomaly characterized by increased pulmonary blood flow which in severe cases results in pulmonary hypertension subjecting the right ventricle to strain. An epidural catheter was placed at the $T_{11}-T_{12}$ interspace and anaesthesia was established to the $T_{4}$ dermatomal level with bupivacaine $(180 \mathrm{mg})$ and didocaine $(100 \mathrm{mg})$. Central venous pressure, pulmonary artery pressure, radial artery pressure, and cardiac output were monitored. There was minimal change in pulmonary arterial pressure, although there was a significant drop in systemic arterial pressure. Thoracic epidural block is recommended for kpper abdominal surgery in clinical situations with pulmonary hypertension.

\section{Key Words}

ANAESTHETIC TECHNIQUES: epidural; LUNG: pulmonary artery hypertension.
\end{abstract}

From the Department of Anesthesia, Brigham \& Women's Hospital, Harvard Medical School.

Address correspondence to: Dr. S. Rao Mallampati, Dept. of Anesthesia, Brigham \& Women's Hospital, Harvard Medical School, 75 Francis Street, Boston, MA 02115
Partial anomalous pulmonary venous return without an associated atrial septal defect is an uncommon congenital lesion resulting in a high pulmonary arterial pressurc. The purpose of this paper is to review briefly the pathophysiology of the disease and to present the anaesthetic management of a patient who underwent elective cholecystectomy.

\section{Case Report}

A 52-year-old man, $185 \mathrm{~cm}$ tall and weighing $95 \mathrm{~kg}$, known to have cholelithiasis for approximately ten years, was scheduled for cholecystectomy. Approximately two months previously he had suffered an episode of pancreatitis when the serum bilirubin rose to $11 \mathrm{mg} / \mathrm{dl}$ and serum amylase to $700 \mathrm{IU} / \mathrm{L}$ (normal 5-75 IU/L). Following recovery from pancreatitis, cholecystectomy was planned. His past medical history included essential hypertension of approximately ten years duration. Ten years previously he underwent appendectomy under general anaesthesia at another hospital where the postoperative course was complicated by the development of pulmonary infection and fever.

On the present admission be reported easy fatigability and progressively increasing exertional dyspnea of approximately two years duration. Oral medications included alpha-methyldopa $250 \mathrm{mg}$ TID and hydrochlorothiazide $50 \mathrm{mg}$ daily for essential hypertension. Several years previously be successfully overcame a long standing problem with alcohol addiction. He had smoked a package of 
cigarettes daily for over 20 years. He had no known allergies.

Physical examination revealed a well-developed, well-nourished man, with blood pressure of $130 / 100$ torr, pulse rate of 85 and respiratory rate of 16. There was no jugular venous distension or cyanosis. His fingers displayed a moderate degree of clubbing. The lungs were clear to percussion and auscultation. Examination of the heart was unremarkable except for a grade $2 / 6$ ejection systolic murmur along the upper left sternal border. A chest roentgenogram demonstrated an enlarged pulmonary artery and clear lungs. An electrocardiogram showed normal sinus rhythm, right bundle branch block and right ventricular hypertrophy. Echocardiography displayed an enlarged and hypertrophied right ventricle. Laboratory data were as follows: haemoglobin $15 \mathrm{gm} / \mathrm{dl}$, haematocrit 44 per cent, serum potassium $4.1 \mathrm{mEq} / \mathrm{L}$, sodium $139 \mathrm{mEq} / \mathrm{L}$ chloride $102 \mathrm{mEq} / \mathrm{L}$, alkaline phosphatase $156 \mathrm{IU} / \mathrm{L}$ (nonnal 16-195 IU/L), amylase $91 \mathrm{IU} / \mathrm{L}$ (normal 5-75 IU/L), total bilirubin $1.7 \mathrm{mg} / \mathrm{dl}$, direct bilirubin $0.9 \mathrm{mg} / \mathrm{dl}$, serum glutamic-oxaloacetic transaminase (SGOT) $59 \mathrm{IU} / \mathrm{L}$ (normal 18-33 IU/L), serum glutamic-pyruvic transaminase (SGPT) $31 \mathrm{IU} / \mathrm{L}$ (nomal 5-35IU/L), and lactic dehydrogenase (LDH) $231 \mathrm{IU} / \mathrm{L}$ (normal 88-196 IU/L). Pulmonary function tests demonstrated a forced vital capacity (FVC) of 3.46 liters (65 per cent predicted), forced vital capacity in one second (FEV $)_{1}$ ) 1.94 liters (51 per cent predicted) and $\mathrm{FEV}_{1} / \mathrm{FVC}=56$ per cent. Arterial blood gas analysis $\left(\mathrm{Fl}_{\mathrm{O}_{2}}=0.21\right) \mathrm{PO}_{2} 61$ torr, $\mathrm{PCO}_{2} 31$ torr pH 1.45 , base excess -1.0 . Table I summarizes the preoperative cardiac catheterization data. The cardiac status was class III (New York Heart Association).

Prior to induction of anaesthesia, a Swan-Ganz catheter, a central venous pressure (CVP) catheter, a cannula for the left radial artery, and one large-bore intravenous line were inserted. Heart rate, CVP, systemic and pulmonary pressures, the electrocardiogram and arterial blood gases were monitored. Serial cardiac outputs (right ventricular outputs measured with the thermodilution technique) were measured. As general anaesthesia was complicated by pulmonary infection previously, a regional anaesthetic procedure was chosen for this patient. Low thoracic epidural block was preferred over spinal anaesthesia in an attempt to avoid rapid fluctuations in blood pressure. An epidural catheter was placed at the $T_{11}-T_{12}$ interspace uneventfully. Following a test dose $(2 \mathrm{ml})$, a dose of $10 \mathrm{ml}$ of 0.75 per cent bupivacaine was given, supplemented with $5 \mathrm{ml}$ of 2 per cent lidocaine as anaesthesia was incomplete at the outset. Anaesthesia to pinprick to the fourth thoracic dermatome was subsequently attained. $\mathrm{A} \mathrm{T}_{4}$ level of anaesthesia was maintained with two subsequent doses of $6 \mathrm{ml}$ and $5 \mathrm{ml}$ of 0.75 per cent bupivacaine. Supplemnental oxygen was administered via a mask at eight liters per minute. A total of $17.5 \mathrm{mg}$ of diazepam and $100 \mu \mathrm{g}$ of fentanyl were given for sedation. Estimated blood loss was $400 \mathrm{ml}$ while intraoperative fluid administration consisted of $400 \mathrm{ml}$ of 5 per cent dextrose in water and $1,600 \mathrm{ml}$ of lactated Ringer's solution. There was no noteworthy change in pulmonary arterial pressure, as contrasted with a slight drop in the systemic arterial pressure (Table 11). The patient tolerated the procedure well and the postoperative course was uneventful.

\section{Pathophysiology of Anomalous Pulmonary Venous Return}

A pulmonary vein is anomalously connected when it fails to communicate normally with the left atrium and instead connects to the right side of the heart via the right atrium, coronary sinus or venae cavae or tributaries. ${ }^{1}$ Partial anomalous pulmonary venous connection is present when some, but not all, pulmonary veins are aberrantly connected. This condition is so uncommon, however, that only 20 cases of partial anomalous pulmonary venous connection without associated atrial septal defect were encountered at the Mayo Clinic between 1953 and $1966^{2}$

Partial anomalous pulmonary venous return without associated atrial septal defect permits a portion of oxygenated blood to mix with the systemic venous blood, leading to arterialization of the latter, in effect a left-to-right shunt in the absence of an intracardiac left-to-right communication. As right atrial pressure is lower than the left atrial pressure, resistance to flow from pulmonary artery to right atrium is lower than that from the pulmonary artery to the left atrium. ${ }^{3}$ Consequently the magnitude of blood flow through the anomalous vein draining into the right atrium is considerably higher than expected if the vein opened normally into the left atrium. The net result is an increase in 
TABLE I Preoperative Cardiovascular Dala

\begin{tabular}{|c|c|c|c|c|c|}
\hline $\begin{array}{l}\text { Saturation-Oximetry } \\
\text { (\%) }\end{array}$ & Site & $\begin{array}{l}\text { Pressure at } \\
\text { Rest (mmHg) }\end{array}$ & $\begin{array}{l}\text { Pressure after } \\
\text { Inhalation of } \\
\text { lo0\% } \mathrm{O}_{2} \text { by } \\
\text { Maskfor } 10 \mathrm{~min} .\end{array}$ & $\begin{array}{l}\text { Pressure after } \\
\text { Sodium Nitroprusside } \\
\text { Infusion } \\
\text { (up to } 200 \mu \mathrm{g} / \mathrm{min} . \text { ) }\end{array}$ & Normal Value \\
\hline $\begin{array}{l}\text { Superior Vena Cava } \\
\text { (SVC) } 58\end{array}$ & $\begin{array}{l}\text { Right atrium: } \\
\text { Mean (M) }\end{array}$ & 17 & - & - & $0-8$ \\
\hline $\begin{array}{l}\text { Right Atrium } \\
\text { (RA) } 81\end{array}$ & $\begin{array}{l}\text { Right ventricle: } \\
\text { Systolic (S) } \\
\text { end-diastolic (ED) }\end{array}$ & $\frac{100}{22}$ & - & - & $\frac{15-30}{0-8}$ \\
\hline $\begin{array}{l}\text { Main Pulmonary Antery } \\
\text { (MPA) } 72\end{array}$ & Pulmonary artery: & & & & \\
\hline $\begin{array}{l}\text { Right Pulmonary Artery } \\
\text { (RPA) } 70\end{array}$ & $\frac{\mathbf{s}}{\mathrm{ED}}$ & $\frac{100}{55}$ & $\frac{95}{55}$ & $\frac{85}{55}$ & $\frac{15-30}{4-12}$ \\
\hline $\begin{array}{l}\text { Left Ventricle } \\
\text { (LV) } 90\end{array}$ & $\mathbf{M}$ & 72 & 70 & 65 & $9-16$ \\
\hline \multirow[t]{8}{*}{ Systemic Artery 85} & $\begin{array}{l}\text { Pulmonary artery } \\
\text { wedge pressure (M) }\end{array}$ & 22 & 22 & 26 & $1-10$ \\
\hline & Left ventricle: $\frac{S}{E D}$ & $\frac{170}{25}$ & $\frac{160}{26}$ & $\frac{110}{16}$ & $\frac{100-140}{3-12}$ \\
\hline & Systemic artery: $\frac{\text { S }}{\bar{E} D}$ & $\frac{170}{122}$ & $\frac{160}{120}$ & $\frac{110}{90}$ & $\frac{100-140}{60-90}$ \\
\hline & $M$ & 140 & 140 & 85 & $70-105$ \\
\hline & $\begin{array}{l}\text { Systemic vascular } \\
\text { resistance } \\
\text { (Dynes-sec-cm-5) }\end{array}$ & 2811 & - & - & $770-1500$ \\
\hline & $\begin{array}{l}\text { Pulmonary vascular } \\
\text { resistance } \\
\text { (Dynes-sec-cm } \\
\text { (D) }\end{array}$ & 714 & - & - & $20-120$ \\
\hline & $\begin{array}{l}\text { Pulmonary blood flow } \\
\text { (liters/minute) }\end{array}$ & 5.6 & - & - & - \\
\hline & $\begin{array}{l}\text { Systemic blood flow } \\
\text { (liters/minute) }\end{array}$ & 3.5 & - & - & - \\
\hline
\end{tabular}

pulmonary blood flow to a degree depending on the number of veins opening into the right side of the heart, pulmonary vascular resistance and the pressure gradient between right and left atria. However, since the pulmonary circulation is a low resistance system in postnatal life and in health, small increases in pulmonary blood flow do not usually cause a corresponding increase in pulmonary vascular pressures. This physiologic property results from the high distensibility of the pulmonary vascular bed which is attributed to its sparse smooth-muscle elements, scant nerve supply, and absence of valves. ${ }^{4}$ But as the pulmonary blood flow approaches approximately three times normal, the vascular bed might not be able to buffer the increased flow by further distension and the pressure will rise sharply above normal ${ }^{5,6}$ Once pulmonary hypertension is established and chronic, it triggers anatomic changes in the small pulmonary arteries in the form of medial hypertrophy, intimal hyperplasia and fibrosis. These changes per se increase resistance to pulmonary blood flow and exacerbate the increased pulmonary arterial pressure. The net effect is a vicious cycle of deterioration, leading to cor pulmonale.

\section{Discussion}

A literature search revealed no information on use 
of thoracic epicural anaesthesia in relation to primary or secondary pulmonary hypertension. Lumbar epidural anaesthesia was safely used in Eisenmenger's syndrome, ${ }^{7}$ where pulmonary hypertension exists. Thoracic epidural anaesthesia was chosen in this case because of the pathophysiology of the syndrome and the upper abdominal location of the procedure. As the right ventricle is subject to strain and cor pulmonale is common, it seemed prudent to avoid use of drugs that can cause significant myocardial depression. Most inhalation agents in current use are powerful myocardial depressants. Additionally, nitrous oxide increases systemic vascular resistance, presumably from sympathetic stimulation, ${ }^{8}$ and also raises pulmonary vascular resistance. ${ }^{9,10}$ Use of these agents can be detrimental in patients with compromised myocardial function and therefore was avoided in this patient. However, epidural block could also affect putmonary haemodynamics through sympathetic blockade and myocardial depression produced by the local anaesthetic. The depressant effect on the myocardium is believed to be mild except in association with an overdose of local anaesthetic. The pulmonary sympathetic innervation arises from $\mathrm{T}_{2}-\mathrm{T}_{4}$ and is distributed mainly to pulmonary and bronchial vessels. ${ }^{11}$ As the cutaneous level of anaesthesia to pinprick was $T_{4}$, blockade of pulmonary sympathetics was more than likcly to be complete, since the sympathetic block exceeds the sensory block, usually by approximately two to three segments and sometimes by as many as six segments. ${ }^{12}$ Nonetheless the fall in pulmonary arterial pressures was hardly significant. This contrasts with the fall in systemic arterial pressure (Table II), a difference perhaps explainable in that the pulmonary vessels are anatomically and physiologically different from the systemic vessels. The former have sparse smooth muscle and scant innervation as contrasted with the latter. Therefore, one might expect a less pronounced effect from pulmonary sympathetic blockade as compared with the effect from systemic sympathetic blockade.

The writer believes that thoracic cpidural block is therapeutically a sound technique in situations where pulmonary hypertension exists.

\section{Acknowledgement}

I am indebted to Leroy D. Vandam, MD, Professor of Anaesthesia, Emeritus, Harvard Medical
TABLE II Haemodynamic Functions Before and After the Epidural Block

\begin{tabular}{|c|c|c|}
\hline Hemodynamic Function & $\begin{array}{l}\text { Before } \\
\text { Epidural Block }\end{array}$ & $\begin{array}{l}\text { After } \\
\text { Epidural Block }\end{array}$ \\
\hline Heart rate (beats/minute) & 92 & 96 \\
\hline $\begin{array}{l}\text { Right ventricular output } \\
\text { (liters/minute) }\end{array}$ & 9.1 & 7.8 \\
\hline $\begin{array}{l}\text { Radial artery pressure: } \\
\text { Systolic } \\
\text { Diastolic ; mean (tor) }\end{array}$ & $\frac{140}{80} ; 102$ & $\frac{115}{70} ; 88$ \\
\hline $\begin{array}{l}\text { Pulmonary artery pressur } \\
\frac{\text { Systolic }}{\text { Diaslolic }} \text {; mean (torr) }\end{array}$ & $\frac{75}{40} ; 55$ & $\frac{72}{38} ; 54$ \\
\hline $\begin{array}{l}\text { Central venous pressure } \\
\text { (mean:torr) }\end{array}$ & 14 & 13 \\
\hline Systemic arterial blood ga & & \\
\hline $\mathrm{PO}_{2}$ & 64 & 68 \\
\hline $\mathrm{PCO}_{2}$ & 33 & 35 \\
\hline $\mathrm{pH}$ & 7.45 & 7.43 \\
\hline$\left[\mathrm{H}^{+}\right]$ & 35.5 & 37.2 \\
\hline$\%$ Saturation & 91.3 & 92 \\
\hline Base excess (mEq/L) & 0 & 0 \\
\hline
\end{tabular}

School, for editorial advice in preparing the manuscript

\section{References}

1 Mascarenhas E, Javier RP, Samet P. Partial anomalous pulmonary venous connection and drainage. Am J Cardiol 1973; 31: 512-8.

2 Frye RL, Krebs M, Rahimtoola SH, Ongley PA, Hallermann FJ, Wallace RB. Partial anomalous pulmonary venous connection without atrial septal defect. Am J Cardiol 1968; 22: 242-50.

3 Rudolph AM. Congenital Disease of the Heart. Chicago: Year Book Medical Publishers, 1974: pp. 239-264.

4 Enson Y. Pulmonary heart disease: Relation of pulmonary hypertension to abnormal lung structure and function. Bull NY Acad Med 1977; 53: 551 -66.

5 Cournand A, Riley RL, Himmelstein A, et al. Pulmonary circulation and alvcolar ventilationperfusion relationships after pneumonectony. J Thorac Surg 1950; 19: 80-116.

6 Lategola $M T$. Pressure-flow relationships in the dog lung during acute subtotal pulmonary vascular acclusion. Am J Physiol 1958; 192: 613-9.

7 Spinnato JA, Kraynack BJ, Cooper MW. Eisenmenger's Syndrome in pregnancy: Epidural 
anesthesia for elective cesarean section. N Engl J Med 1981; 304: 1215-7.

8 Fukunaga AF, Epstein RM. Sympathetic excitation during nitrous oxide-halothane anesthesia in the cat. Anesthesiology 1973; 39: 23-6.

9 Lappas DG, Buckley MJ, Laver MB, et al. Left ventricular performance and pulmonary circulation following addition of nitrous oxide to morphine during coronary-artery surgery. Anesthesiology 1975; 43: 61-9.

10 Hilgenberg JC, McCammon RL, Stoelting $R K$. Pulmonary and systemic vascular responses to nitrous oxide in patients with mitral stenosis and pulmonary hypertension. Anesth Analg 1980; 59 : 323-6.

11 Widdicombe JG, Sterling GM. The autonomic nervous system and breathing. Arch Intern Med 1970; 126: 311-29.

12 Greene NM. Physiology of Spinal Anesthesia, 3rd ed. Baltimore: Williams \& Wilkins, 1981: pp. 27-28.
Résumé

On a administré à un patient de 52 ans, se présentant avec hypertension putmonaire, secondaire à celle du retour veineux pulmonaire anomal mais ne se rapportant pas à la communication interauriculaire, l'anesthésie épidurale afin de faire l'opération de la cholécystomie. Un retour putmontaire partiel et veineux est une anomalie congénitale, caraciérisée par l'augmentation du débit pulmonaire sanguin qui, dans des cas graves, produit l'hypertension pulmonaire ayant pour résultat une surcharge d' effort du ventricule cardiaque droit. On a placé un cathéter épidural au $T_{11}-T_{12}$ et l'anesthésie a êté administrée au niveau sous-cutané du $T_{4}$ avec de la bupivacaine ( $180 \mathrm{mg}$ ) et de la lidocaine $(100 \mathrm{mg})$. La pression veineuse centrale, la pression de l'artère pulmonaire, celle de l'artère radiaie et le débit cardiaque ont été contrólés. On observa seulement un changement minime de la pression artérielle pulmonaire mais la pression artérielle systémique baissa de manière significative. $L$ anesthésie épidurale thoracique est donc recommandée dans les cas de chirurgie abdominale supérieure où il y a hypertension pulmonaire. 